\title{
Hubungan Verbal Bullying dengan Kecerdasan Interpersonal Peserta Didik SD
}

\author{
Ahmad Fadhlilah, Ika W. Utamining Tias \\ Pendidikan Guru Sekolah Dasar, Universitas Lampung \\ Jl. Prof. Dr. Sumantri Brojonegoro No 1 Bandar Lampung \\ E-mail: ahmadfadhlilah1605@gmail.com
}

\section{Article Info}

Received September 2020 Accepted Oktober 2020 Published Oktober 2020

Keywords:

interpersonal intelegence, verbal bullying.

Abstract

The problem in this research was the existence of verbal bullying behavior and its relation to the students' interpersonal intelegence in fourth class Primary School state in Budi Utomo Cluster District Sub of Metro Selatan Metro City. This research aims to determine the significant relationship between verbal bullying with intellegence interpersonal students. This type of research is ex-postfacto correlation. The population is 78 students and all populations are used as research samples. The instrument for data collection is a questionnaire with a Likert scale, which was previously tested for validity and reliability. Data analysis used product moment correlation. Based on the analysis conducted by the results of the study it can be concluded that there is a positive and significant relationship between verbal bullying with intellegence interpersonal indicated by a correlation coefficient at the level of "High Enough".
\end{abstract}

\begin{abstract}
Abstrak : Masalah dalam penelitian ini adalah adanya perilaku verbal bullying serta keterkaitanya dengan kecerdasan interpersonal peserta didik di kelas IV SD Negeri se-Gugus Budi Utomo Kecamatan Metro Selatan Kota Metro. Penelitian ini bertujuan untuk mengetahui hubungan yang signifikan antara verbal bullying dengan kecerdasan interpersonal. Jenis penelitian yaitu ex-postfacto korelasi. Populasi berjumlah 78 orang peserta didik dan semua populasi dijadikan sampel penelitian. Instrumen pengumpul data berupa angket dengan skala Likert, yang sebelumnya diuji validitas dan reliabilitas. Analisis data menggunakan korelasi product moment. Berdasarkan analisis yang dilakukan hasil penelitian dapat disimpulkan bahwa terdapat hubungan yang positif dan signifikan antara verbal bullying dengan kecerdasan interpersonal peserta didik ditunjukkan dengan koefisien korelasi berada pada taraf "Cukup Kuat".
\end{abstract}

Kata kunci : Kecerdasan Interpersonal, Verbal Bullying.

C2020 Jurusan Ilmu Pendidikan, FKIP Universitas Lampung 


\section{PENDAHULUAN}

Pendidikan juga merupakan salah satu sarana untuk mengembangkan potensi diri dan keterampilan peserta didik melalui proses pembelajaran sebagai bekal bagi dirinya menjalani hidup bermasyarakat, berbangsa, dan bernegara. Undang-undang No. 20 Tahun 2003 tentang Sistem Pendidikan Nasional bab I ayat 1 pasal 1 secara tegas dinyatakan bahwa pendidikan merupakan usaha sadar dan terencana untuk mewujudkan suasana belajar dan proses pembelajaran agar peserta didik secara aktif mengembangkan potensi dirinya untuk memiliki kekuatan spiritual keagamaan, pengendalian diri, kepribadian, kecerdasan, akhlak mulia, serta keterampilan yang diperlukan dirinya, masyarakat, bangsa, dan negara.

Proses pendidikan yang layak dalam suatu negara harus sangat diperhatikan oleh seluruh kalangan. Proses pendidikan sendiri tidak hanya terjadi di lingkup sekolah saja, tetapi proses pendidikan ini dapat terjadi dimana saja, salah satunya lingkup keluarga, termasuk juga di lingkungan sekitar dimana peserta didik berinteraksi dengan orang lain. Proses dalam dunia pendidikan yang kurang diperhatikan juga yang dapat menghambat proses pendidikan. Hambatan dalam dunia pendidikan yang terjadi di era modern ini sangatlah banyak jenisnya baik yang berdampak pada hasil belajar, kualitas pendidikan, serta kecerdasan interpersonal peserta didik. Menurut Riyanto (2009) kecerdasan interpersonal adalah kemampuan untuk membedakan dan memberikan persepsi tentang motivasi, suasana hati, dan perasaan orang lain dengan kemampuan menanggapinya secara efektif.

Salah satu faktor yang menghambat kecerdasan interpersonal peserta didik adalah perilaku bullying yang diterima oleh peserta didik baik verbal bullying maupun non-verbal bullying. Pratiwi (2016) menjelaskan bahwa bullying berpengaruh terhadap kehidupan sosial anak yang membuat kecerdasan interpersonal anak terhambat sehingga membuat peserta didik tidak dapat bergaul dengan baik kepada lingkungannya, hal tersebut terjadi karena kemampuan interaksi sosial peserta didik yang masih rendah. Terjadinya verbal bullying di sekolah saat ini sangat memprihatinkan bagi pendidik, orang tua, dan masyarakat. Seperti yang dikataan Bond, dkk dalam Lomas, Stough, Hansen \& Downey (2011) Being a target of bullying has been 
found to have negative impacts upon social and emotional wellbeing, academic performance and success later in life (Menjadi target bullying telah memiliki dampak negatif pada kesejahteraan sosial dan emosional, kinerja akademik dan kesuksesan di kemudian hari). Olweus, dkk dalam (Lomas, Stough, Hansen \& Downey 2011) mengungkapkan bahwa Considered to be a form of aggression, bullying behaviours are characterised by intent, power imbalance and are repeated over time (Dianggap sebagai bentuk agresi, perilaku bullying dicirikan oleh niat, ketidakseimbangan kekuatan dan diulang dari waktu ke waktu).

Pengertian bullying yang diutarakan Olweus dalam (Ploeg, Steglich, \& Veenstra, 2020) Bullying is commonly defined as repetitive and intentionally negative behavior against a victim who finds it difficult to defend him-or herself (Penindasan umumnya didefinisikan sebagai perilaku berulang dan sengaja negatif seorang korban yang merasa sulit untuk mempertahankan dirinya). Suciartini (2018) menjelaskan bahwa verbal bullying merupakan saat seseorang menggunakan perkataan untuk mendapatkan kuasa di antara sesamanya. Walaupun verbal bullying tidak menyebabkan kerusakan fisik, tapi penekanan seperti ini dapat memberikan dampak buruk pada sisi psikologis korban. Perilaku bullying pada anak dapat terjadi dimana saja, salah satunya adalah di sekolah. Sebagaimana data Komisi Perlindungan Anak Indonesia (KPAI) yang dikutip dari Tempo.co (2018) tanggal 30 Mei 2018, jumlah kasus pendidikan mencapai 161 kasus dengan kasus bullying paling banyak. Terdapat 36 kasus atau 22,4\% kasus korban kekerasan dan bullying, 41 kasus atau 25,5\% kasus pelaku kekerasan dan bullying, dengan kata lain, hampir separuh dari kasus pendidikan adalah kasus jenis kekerasan dan bullying.

Berdasarkan hasil observasi, wawancara yang telah dilaksanakan pada Oktober 2019, dan penyebaran angket pendahuluan yang dilaksanakan oleh peneliti pada November 2019 terdapat beberapa masalah yang berpengaruh pada perkembangan kecerdasan interpersonal peserta didik yang timbul akibat perilaku verbal bullying yang dialaminya, antar lain: 1) Sebagian peserta didik tidak aktif ketika melaksanakan pembelajaran; 2) Sebagian peserta didik cenderung menyendiri di dalam kelas ketika jam istirahat berlangsung; 3) Sebagian peserta didik takut bekerjasama ketika pembelajaran berbentuk kelompok; 4) Sebagian peserta didik takut menyampaikan pendapat di depan teman temannya; 5) Sebagian peserta didik bertingkah laku kurang sopan 
kepada teman di lingkungan sekolahnya; 6) Sebagian peserta didik kecerdasan interpersonalnya bermasalah.

Berdasarkan dari hasil perhitungan angket yang disebarkan kepada seluruh peserta didik kelas IV SD Negeri se-Gugus Budi Utomo Kecamatan Metro Selatan tahun pelajaran 2019/2020 dapat disimpulkan bahwa sebesar $50,04 \%$ peserta didik menjadi korban verbal bullying yang berpotensi memiliki hubungan dengan kecerdasan interpersonal peserta didik. Hal ini yang mendorong peneliti untuk melakukan penelitian dengan judul "Hubungan Verbal bullying dengan Kecerdasan Interpersonal Peserta Didik Kelas IV SD Negeri se-Gugus Budi Utomo Kecamatan Metro Selatan Kota Metro".

\section{METODE}

\section{Jenis Penelitian}

Jenis penelitian yang digunakan adalah penelitian kuantitatif. Metode yang digunakan dalam penelitian ini adalah ex-postfacto korelasional. Jenis penelitian ini dilakukan ketika ingin mengetahui tentang kuat atau lemahnya hubungan antara dua variabel atau lebih. Arikunto (2010) menjelaskan bahwa penelitian korelasional adalah penelitian yang dilakukan oleh peneliti untuk mengetahui tingkat hubungan antara dua variabel atau lebih, tanpa melakukan perubahan, tambahan atau manipulasi terhadap data yang sudah ada. Penelitian ini bertujuan untuk mengetahui tingkat hubungan antara verbal bullying dengan kecerdasan interpersonal peserta didik kelas IV SD Negeri seGugus Budi Utomo Kecamatan Metro Selatan, Kota Metro.

\section{Prosedur}

Tahap penelitian ex-postfacto korelasi yang telah dilaksanakan oleh peneliti adalah (1) Memilih subjek penelitian yaitu peserta didik kelas IV SD Negeri se-Gugus Budi Utomo Kecamatan Metro Selatan Kota Metro, (2) Menyusun kisi-kisi dan instrumen pengumpul data berupa angket, (3) Melakukan uji coba instrumen dengan membagikan instrumen angket di SD Negeri 8 Metro Timur, (4) Menganalisis data dari hasil uji coba instrumen untuk mengetahui apakah intrumen yang dibuat telah valid dan reliabel, (5) Melaksanakan penelitian dengan membagikan instrumen angket kepada sampel penelitian, (6) Menghitung data yang diperoleh untuk mengetahui 
hubungan dan tingkat keterkaitan antara verbal bullying dengan kecerdasan interpersonal peserta didik kelas IV SD Negeri se-Gugus Budi Utomo Kecamatan Metro Selatan, Kota Metro dan Interpretasi hasil perhitungan, (7) Interpretasi data hasil penelitian.

\section{Populasi dan Sampel}

Populasi dalam penelitian ini semua peserta didik kelas IV SD Negeri seGugus Budi Utomo Kecamatan Metro Selatan, Kota Metro tahun pelajaran 2019/2020. Teknik pengambilan sampel dalam penelitian ini sampel jenuh, Menurut Sugiyono (2014) sampling jenuh adalah teknik penentuan sampel bila semua anggota populasi digunakan sebagai sampel atau penelitian yang membuat generalisasi dengan kesalahan yang sangat kecil. Istilah lain sampel jenuh adalah sensus, dimana semua anggota populasi dijadikan sampel. Populasi dalam penelitian ini berjumlah 78 orang peserta didik dan semua populasi dijadikan sampel penelitian.

\section{Teknik Pengumpulan Data}

Teknik pengumpulan data yang digunakan berupa observasi, wawancara, kuesioner (angket), dan studi dokumentasi. Observasi dalam penelitian ini dilakukan untuk memperoleh data tentang kondisi sekolah atau deskripsi tentang lokasi penelitian yang dilaksanakan di SD Negeri se-Gugus Budi Utomo Kecamatan Metro Selatan, Kota Metro. Pada penelitian ini peneliti melakukan wawancara terhadap tiap wali kelas IV SD Negeri se- Gugus Budi Utomo Kecamatan Metro Selatan, Kota Metro. Angket atau kuesioner diberikan kepada peserta didik untuk memperoleh informasi mengenai verbal bullying dan kecerdasan interpersonal yang di pegaruhi oleh perilaku menyimpang yang dilakukan oleh peserta didik lain. Angket atau kuesioner ini dibuat dengan model Likert yang mempunyai empat kemungkinan jawaban yang berjumlah genap ini dimaksud untuk menghindari kecenderungan responden bersikap ragu-ragu dan tidak mempunyai jawaban yang jelas, dengan menggunakan skala Likert, maka variabel yang diukur dijabarkan menjadi indikator variabel. Indikator dijadikan sebagai tolak ukur untuk menyusun item-item instrumen yang dapat berupa pertanyaan atau pernyataan dengan jumlah angket sebanyak 44 soal untuk verbal bullying dan 40 soal untuk kecerdasan 
interpersonal. Studi dokumentasi perlu digunakan sebagai sumber data dalam penelitian. Riduwan (2014) menjelaskan studi dokumentasi adalah cara untuk memperoleh data langsung dari tempat penelitian, meliputi buku-buku yang relevan, peraturan-peraturan, laporan kegiatan, foto-foto, dan data yang relevan dengan penelitian.

\section{Instrumen Penelitian}

Instrumen penelitian ini berupa angket verbal bullying dan angket kecerdasan interpersonal. Indikator angket verbal bullying menurut Putri (2013) yaitu (1) Mengejek, (2) Memanggil dengan sebutan buruk atau nama orang tua, (3) Membentak, (4) Mengeluarkan kata-kata kasar, (5) Mengancam, (6) Sering memerintah, (7) Menyoraki, (8) Memfitnah, (9) Mempermalukan, (10) Menakut-nakuti, (11) Menyebarkan gosip buruk. Adapun indikator angket kecerdasan interpersonal menurut Gunawan (2012) yaitu (1) Membentuk dan mempertahankan suatu hubungan sosial, (2) Mampu berinteraksi dengan orang lain, (3) Mengenali dan menggunakan berbagai cara untuk berhubungan, (4) Mampu mempengaruhi pendapat dan tindakan orang lain, (5) Turut serta dalam upaya bersama dan mengambil berbagai peran yang sesuai, mulai dari menjadi pengikut hingga menjadi pemimpin, (6) Mengamati perasaan, pikiran, motivasi, perilaku dan gaya hidup orang lain, (7) Mengerti dan berkomunikasi dengan efektif, (8) Mampu bekerjasama dengan orang yang mempunyai latar belakang yang beragam, (9) Tertarik menekuni bidang yang berorientasi interpersonal, manajemen, atau politik, (10) Peka terhadap perasaan, motivasi, dan keadaan mental seseorang. Instrumen penelitian diuji coba sebelum digunakan sebagai alat pengumpul data. Tujuan uji coba instrumen ini untuk menentukan validitas dan reliabilitas angket yang dibuat sehingga angket verbal bullying dan angket kecerdasan interpersonal layak digunakan untuk penelitian dan dapat mengumpulkan data yang sesuai dengan apa yang diteliti.

\section{Teknik Analisis Data}

Teknik analisis data untuk menguji hipotesis menggunakan rumus Korelasi Product Moment yang diungkapkan oleh Pearson (dalam Muncarno, 2017), dengan data yang diperoleh dari angket peserta didik kelas IV SD Negeri se-Gugus Budi Utomo Kecamatan Metro Selatan Kota Metro tahun pelajaran 
2019/2020. Sebelum dilaksanakan analisis data terlebih dahulu, peneliti harus melakukan pungujian prasyarat analisis dengan menguji normalitas dan linearitas data. Uji hipotesis menggunakan ru-mus korelasi Product Moment, dan uji-F, sedangkan menentukan besar kecilnya kontribusi variabel X (verbal bullying) terhadap Y (kecerdasan interpersonal) dengan rumus koefisien determinan. Adapun signifikansi hubungan dilihat dari hasil perhitungan uji-F dengan kaidah: jika $\mathrm{F}_{\text {hitung }}>\mathrm{F}_{\text {tabel, }}$ artinya terdapat hubungan yang sig-nifikan atau hipotesis penelitian di-terima. Sedangkan jika $t_{\text {hitung }}<t_{\text {tabel, }}$, artinya tidak terdapat hubungan yang signifikan atau hipotesis penelitian ditolak.

\section{HASIL DAN PEMBAHASAN}

Berdasarkan hasil instrumen angket yang diberikan kepada peserta didik kelas IV SD Negeri se-Gugus Budi Utomo Kota Metro pada Januari 2020 didapati data sebagai berikut.

Tabel 1. Jumlah Sampel Berdasarkan Lokasi Penelitian dan Gender

\begin{tabular}{lcc}
\hline \multirow{2}{*}{ Data } & \multicolumn{2}{c}{ Variabel } \\
\cline { 2 - 3 } & $\mathrm{X}$ & Y \\
\hline $\mathrm{N}$ & 78 & 78 \\
Skor Terbesar & 79 & 81 \\
Skor Terkecil & 45 & 47 \\
$\sum$ & 4790 & 4946 \\
Rerata & 61,62 & 63,17 \\
Simpangan baku (S) & 8,05 & 8,95 \\
\hline
\end{tabular}

Pada tabel 1 menunjukkan bahwa simpangan baku (S) variabel kecerdasan interpersonal (Y) sebesar 8,95 rerata sebesar 63,17 dan jumlah skor angket 4946. Hal tersebut berhubungan dengan data variabel verbal bullying (X) yang memiliki simpangan baku (S) sebesar 8,05 rerata sebesar 61,62 dan jumlah skor angket 4790 .

Berikut deskripsi distribusi frekuensi data variabel X.

Tabel 2. Distribusi Frekuensi Variabel Verbal Bullying $(X)$

\begin{tabular}{ccccl}
\hline No & Kelas Interval & F & Persentase(\%) & \multicolumn{1}{c}{ Kategori } \\
\hline 1 & $45-49$ & 6 & 7.69 & Sangat berat \\
2 & $50-54$ & 10 & 12.82 & Berat \\
3 & $55-59$ & 14 & 17.95 & Cukup berat \\
4 & $60-64$ & 20 & 25.64 & Sedang
\end{tabular}




\begin{tabular}{ccccl}
5 & $65-69$ & 15 & 19.23 & Cukup ringan \\
6 & $70-74$ & 8 & 10.26 & Ringan \\
7 & $75-79$ & 5 & 6.41 & Sangat ringan \\
\hline & Jumlah & 78 & 100 & \\
\hline
\end{tabular}

Berdasarkan tabel 2 dapat dilihat skor terendah dalam angket verbal bullying sebesar 45 dan skor tertinggi yaitu sebesar 79 jika dilihat dari kategorinya, dapat diketahui bahwa sebesar $38,46 \%$ peserta didik menjadi korban verbal bullying berkategori berat, peserta didik menjadi korban verbal bullying berkategori sedang sebesar 25,64\%, dan peserta didik menjadi korban verbal bullying berkategori ringan sebesar 35,9\%, yang artinya peserta didik yang menjadi korban verbal bullying berkategori berat lebih banyak persentasenya dibandingkan dengan peserta didik yang menjadi korban verbal bullying berkategori ringan. Lebih jelasnya dapat dilihat pada gambar berikut.

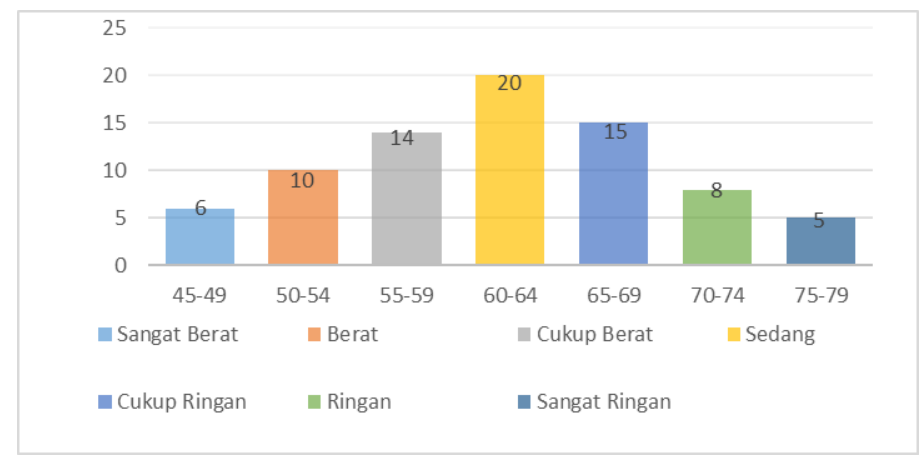

Gambar 1. Distribusi Frekuensi Variabel X

Pada gambar 1 telah disajikan tujuh kelas interval beserta frekuensinya. Berdasarkan diagram yang telah disajikan, dapat diketahui bahwa kelas interval dengan frekuensi tertinggi terletak pada kelas interval 60-64 dengan frekuensi sebanyak 20 orang peserta didik, sementara frekuensi terendah terletak pada kelas 75 -79 dengan frekuansi sebanyak 5 orang peserta didik.

Distribusi frekuensi variabel Y dapat dilihat pada tabel berikut.

Tabel 3. Distribusi Frekuensi Variabel Kecerdasan Interpersonal (Y)

\begin{tabular}{ccccl}
\hline No & Kelas Interval & F & Persentase(\%) & \multicolumn{1}{c}{ Kategori } \\
\hline 1 & $47-51$ & 9 & 11.54 & Sangat rendah \\
2 & $52-56$ & 11 & 14.10 & Rendah \\
3 & $57-61$ & 14 & 17.95 & Cukup rendah \\
4 & $62-66$ & 17 & 21.79 & Sedang
\end{tabular}




\begin{tabular}{ccccl}
5 & $67-71$ & 11 & 14.10 & Cukup tinggi \\
6 & $72-76$ & 9 & 11.54 & Tinggi \\
7 & $77-81$ & 7 & 8.97 & Sangat tinggi \\
\hline & Jumlah & 78 & 100 & \\
\hline
\end{tabular}

Berdasarkan tabel 3 dapat dilihat skor terendah dalam angket kecerdasan interpersonal sebesar 47 dan skor tertinggi yaitu sebesar 81 jika dilihat dari kategorinya, dapat diketahui bahwa sebesar 43,59\% peserta didik memiliki kecerdasan interpersonal berkategori rendah, peserta didik memiliki kecerdasan interpersonal berkategori sedang sebesar $21,79 \%$, dan peserta didik memiliki kecerdasan interpersonal berkategori tinggi sebesar 34,61\%, yang artinya peserta didik yang memiliki kecerdasan interpersonal rendah lebih banyak persentasenya dibandingkan peserta didik yang memiliki kecerdasan interpersonal tinggi. Lebih jelasnya dapat dilihat pada gambar berikut.

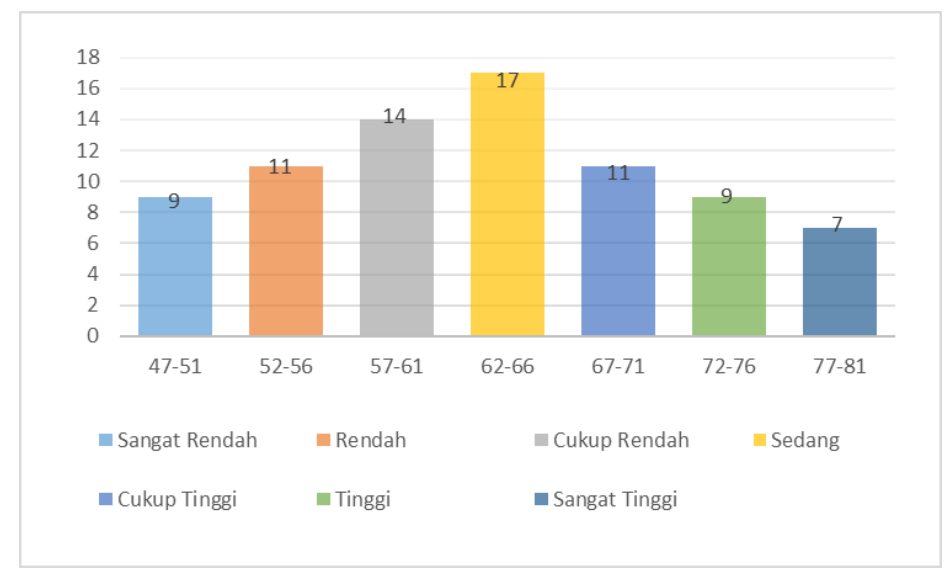

Gambar 1. Distribusi Frekuensi Variabel Y

Pada gambar 2 telah disajikan tujuh kelas interval beserta frekuensi-

nya. Berdasarkan diagram yang telah disajikan, dapat diketahui bahwa kelas interval dengan frekuensi tertinggi terletak pada kelas interval 62-66 dengan frekuensi sebanyak 17 orang peserta didik, sementara frekuensi terendah terletak pada kelas 47-51 dengan frekuensi sebanyak 9 orang peserta didik.

\section{Uji Prasyaratan Analisis Data}

Terdapat dua data yang perlu diuji normalitas, yaitu data variabel $\mathrm{X}$ (verbal bullying), dan Y (kecerdasan interpersonal). Interpretasi hasil 
perhitungan dilakukan dengan membandingkan $X^{2}$ hitung dengan $X^{2}$ tabel untuk $a=0,05$ dengan $\mathrm{dk}=\mathrm{k}-1$. Hasil perhitungan uji norma-litas variabel $\mathrm{X}$ didapati bahwa $X^{2}$ hitung $2,607 \leq X^{2}$ tabel $=12,592$ berarti data variabel $\mathrm{X}$ berdistribusi normal. Sedangkan uji normalitas pada variabel Y didapati bahwa $X^{2}$ hitung $=6,651 \leq X^{2}$ tabel $=12,592$ berarti data variabel $\mathrm{Y}$ berdistribusi normal. Berdasarkan uji normalitas yang menyatakan bahwa data va-riabel X dan $\mathrm{Y}$ berdistribusi normal maka selanjutnya dilakukan uji linearitas. Hasil dari uji linieritas $\mathrm{X}$ dengan $\mathrm{Y}$ didapati bahwa $\mathrm{F}_{\text {hitung }}=0,55 \leq \mathrm{F}_{\text {tabel }}$ 1,72 hal ini berarti data berpola linier.

\section{Uji Hipotesis}

Berdasarkan hasil perhitungan uji hipotesis, koefisien korelasi antara X dengan $\mathrm{Y}$ sebesar 0,414 bertanda positif dengan kriteria cukup kuat. Selanjutnya kontribusi variabel X terhadap variabel Y se-besar 30,49 \%. Hal itu berarti keterampilan mengajar kelompok kecil dan gaya mengajar pendidik memberi pengaruh sebesar $17,14 \%$ sedangkan $82,86 \%$ dipengaruhi oleh faktor lain di luar penelitian ini. Nilai kebermaknaan (sig-nifikansi) sebesar $\mathrm{F}_{\text {hitung }}=$ 15,684> $\mathrm{F}$ tabel $=3,97$ berarti signifikan. Hal ini berarti hipotesis diterima, terdapat hubungan yang positif dan signifikan antara verbal bullying dengan kecerdasan interpersonal peserta didik kelas IV SD Negeri se-Gugus Budi Utomo Kecamatan Metro Selatan, Kota Metro.

\section{Pembahasan}

Berdasarkan perhitungan diperoleh koefisien korelasi antara variabel X dan variabel $\mathrm{Y}$ sebesar 0,414 berarti korelasi tersebut bertanda positif dengan kriteria cukup kuat. Selanjutnya kontribusi varibel $\mathrm{X}$ terhadap variabel $\mathrm{Y}$ sebesar $17,14 \%$. Hal itu berarti verbal bullying memiliki hubungan sebesar $17,14 \%$ terhadap kecerdasan interpersonal. Terdapat hubungan yang positif signifikan antara verbal bullying dengan kecerdasan interpersonal peserta didik SD Negeri se-Gugus Budi Utomo Kecamatan Metro Selatan Kota Metro.

Pendidik dan sekolah memiliki peran yang penting bagi kenyamanan belajar peserta didik seperti yang diungkapkan (Sampson, 2016) bullying affects students' sense of security, the most effective ways to prevent or lessen bullying 
require school administrators' commitment and intensive effort (bullying mempengaruhi rasa aman siswa, cara paling efektif untuk mencegah atau mengurangi intimidasi memerlukan komitmen administrator sekolah dan upaya intensif). Rasa aman dalam belajar dapat berpotensi dlam meningkatkan kecerdasan peserta didik.

Kecerdasan yang paling berpotensi di lingkungan sekolah dasar adalah salah satunya kecerdasan interpersonal. Seperti yang dikatakan (Darmawan \& Hilmawan 2020) Intelligence achieved most dominant among other intelligence is verbal-linguistic intelligence. Quite dominant intelligence is logicalmathematical intelligence and intrapersonal intelligence. Then kinesthetic intelligence, musical intelligence, interpersonal intelligence, spatial-visual intelligence and the last is naturalist intelligence (Kecerdasan paling banyak dicapai dominan di antara kecerdasan lainnya adalah Kecerdasan verballinguistik . kecerdasan yang Cukup dominan adalah logis-matematis intelijen dan kecerdasan intrapersonal. Lalu kecerdasan kinestetik, kecerdasan musikal, kecerdasan interpersonal, spasial-visual kecerdasan dan yang terakhir adalah kecerdasan naturalis. Selain itu, semua indikator verbal-linguistik dan indikator interpersonal dapat tercapai) artinya kecerdasan interpersonal termasuk dalam kecerdasan yang penting karena potensi perkembanganya.

Salah satu faktor yang menghambat kecerdasan interpersonal peserta didik adalah perilaku bullying yang diterima oleh peserta didik terutama verbal bullying. (Okhotan, Hartawan, Okhotan, \& Prabhasuari, 2020) Various studies have found changes in brain structure because of persistent exposure to bullying that affects cognitive and academic achievement (Berbagai penelitian telah menemukan perubahan dalam struktur otak karena paparan bullying yang terus-menerus yang mempengaruhi kognitif dan prestasi akademik). Selain prestasi akademik Pratiwi (2016) menjelaskan bahwa bullying berpengaruh terhadap kehidupan sosial anak yang membuat kecerdasan interpersonal anak terhambat sehingga membuat peserta didik tidak dapat bergaul dengan baik kepada lingkungannya, hal tersebut terjadi karena kemampuan interaksi sosial peserta didik yang masih rendah.

Peserta didik yang menjadi korban verbal bullying tidak dapat bergaul dengan baik dengan lingkunganya karena kondisi mental dan kecerdasan interpersonal korban yang selalu mendapatkan tekanan yang disebabkan verbal 
bullying peserta didik lain. Seperti yang dikatakan oleh Safaria dalam Monawati (2015) bahwa kecerdasan interpersonal menjadi penting dikarenakan pada dasarnya manusia tidak dapat hidup sendiri. Seperti yang dikemukakan oleh (Okhotan, Hartawan, Okhotan, \& Prabhasuari, 2020) The long-term impact of bullying behavior can occur in children who were bullying, namely the emergence of aggressive behavior after the child grows up (dampak jangka panjang dari perilaku intimidasi dapat terjadi pada anak-anak yang mengalami intimidasi, yaitu Munculnya perilaku agresif setelah anak beranjak dewasa). Manusia pada dasarnya dalam kegiatan apapun dituntut untuk berhubungan dengan orang lain. Kecerdasan sosial meliputi kemampuan dan keterampilan seseorang dalam menciptakan relasi, membangun relasi dan mempertahankan relasi sosialnya sehingga kedua belah pihak berada dalam situasi menguntungkan.

Relasi sosial yang terganggu oleh verbal bullying dapat menghambat relasi dengan peserta didik yang lain, jika itu terus berlanjut maka kecerdasan interpersonal peserta didik akan semakin rendah. Efek bullying tidak hanya berlaku saat pembelajaran tetapi efeknya dapat berpengaruh dalam masa depan anak. Seperti yang di kemukakan (Baller, Wenos, \& Peachey, 2019) Bullying and relational aggression are not limited to children and adolescents, These behaviors may persist through post-secondary education and within the workplace (Intimidasi dan agresi relasional tidak terbatas pada anak-anak dan remaja, perilaku ini dapat bertahan melalui pendidikan pasca sekolah menengah dan di tempat kerja). Sebagaimana yang dikemukakan oleh Handini (2013) bahwa kecerdasan interpersonal peserta didik sangat diperlukan dalam kegiatan pembelajaran agar peserta didik dapat melaksanakan kegiatan pembelajaran dengan baik, kecerdasan interpersonal ini dapat memungkinkan peserta didik untuk dapat berkomunikasi dan bersosialisasi dengan temanteman mereka sehingga akan menunjang kemampuan peserta didik dalam belajar.

Selanjutnya dapat disimpulkan bahwa hipotesis yang diajukan peneliti dapat diterima. Berdasarkan hal tersebut, dapat diketahui bahwa terdapat hubungan yang positif dan signifikan antara verbal bullying dengan kecerdasan interpersonal peserta didik kelas IV SD Negeri se-Gugus Budi Utomo 
Kecamatan Metro Selatan Kota Metro. Selanjutnya dapat disimpulkan bahwa hipotesis yang diajukan peneliti dapat diterima.

\section{KESIMPULAN}

Berdasarkan hasil penelitian dan pembahasan diperoleh nilai korelasi antara variabel $\mathrm{X}$ (verbal bullying) dan variabel Y (kecerdasan interpersonal) dengan hasil uji hipotesis sebesar 0,414 sehingga peneliti menyimpulkan bahwa terdapat hubungan yang positif dan signifikan antara verbal bullying dengan kecerdasan interpersonal siswa kelas IV SD Negeri se-Gugus Budi Utomo Kecamatan Metro Selatan Kota Metro. Hasil uji hipotesis sebesar 0,414 termasuk dalam interval koefisien 0,400 - 0,599 dan termasuk dalam kategori cukup kuat.

\section{DAFTAR PUSTAKA}

Arikunto, S. (2010). Prosedur Penelitian Pendekatan Praktek, Jakarta: Rineka Cipta.

Baller, S. L., Wenos, J. Z., \& Peachey, A. A. (2019). Bullying Prevention in an Elementary School: An Exploration of Educator and Staff Perspectives . Journal of Educational Issues, 162-178.

Darmawan, N. H., \& Hilmawan, H. (2020). Multiple Intelligence Potential and Influencing Factors for Elementary School Students Analysis. The 2nd International Conference on Elementary Education, 643-663.

Gunawan, Adi W. (2012). Genius Learning Strategy. Jakarta: PT.Gramedia.

Handini. (2013). Kecerdasan Interpersonal Pada Siswa Kelas IV SD Negeri Kembaran Kulon I. Yogyakarta: Fakultas Ilmu Pendidikan Universitas Negeri Yogyakarta.

Lomas, J., Stough, C., Hansen, K., \& Downey, L. A. (2011). Brief report: Emotional intelligence, victimisation and bullying. Journal of Adolescence,1-5.

Monawati. (2015). Hubungan Antara Kecerdasan Interpersonal Dengan Prestasi Belajar. Jurnal Pesona Dasar. Vol. 3 No. 3: 21 - 32.

Muncarno. (2017). Statistik Pendidikan. Metro: Arthawarna Hamim Group.

Okhotan, C. A., Hartawan, I. G., Okhotan, E. I., \& Prabhasuari, I. A. (2020). Bullying Behavior Affect To Cognitive Development Of Elementary School 
Students In Punggul Village. International Journal of Healthcare Sciences, 53-58.

Ploeg, R. v., Steglich, C., \& Veenstra, R. (2020). The Way Bullying Works: How New Ties Facilitate the Mutual Reinforcement. Social Networks, 1-47.

Pratiwi. (2016). Hubungan Perilaku Bullying dengan Kemampuan Interaksi Sosial Siswa Kelas III SDN Minomartani 6 Sleman. Jurnal Pendidikan Guru Sekolah Dasar. Vol 2 No. 5 : 141-151.

Putri, S. (2013). Profil Perilaku Bullying di Pesantren dan Implikasinya terhadap Bimbingan dan Konseling Pribadi Sosial (Doctoral dissertation, Universitas Pendidikan Indonesia)

Riduwan. (2014). Metode dan Teknik Menyusun Proposal Penelitian. Bandung: Alfabeta.

Riyanto, Yatim. (2009). Paradigma Baru Pembelajaran. Jakarta: Kancana Prenada Media Group.

Sampson, R. (2016). Bullying in Schools. U.S. Department of Justice, 1-48.

Suciartini, dkk. (2018). Verbal Bullying dalam Media Sosial. Jurnal Pendidikan Bahasa Indonesia. Vol. 6 No. 2: 154.

Sugiyono. (2014). Metode Penelitian Pendidikan (Pendekatan Kuantitatif, Kualitatif, dan $R \& D)$. Bandung: Alfabeta.

Tempo.co. (2018). Hari Anak Nasional, KPAI Catat Kasus Bullying. Paling Banyak. 8 Mei 2018. Diambil dari https://nasional.tempo.co/read/1109584/ hari-anak-nasional-kpai-catat-kasus-bullyingpalingbanyak. Diakses pada 12 November 2019.

Undang-undang RI No. 20 Tahun 2003 tentang Sistem Pendidikan Nasional. 